\title{
Recent changes in agrarian systems of the Microregion of Toledo and Northern Pioneer Territory in Paraná State, Brazil
}

\section{Transformações recentes nos sistemas agrários na microrregião de Toledo/PR e no território Norte Pioneiro Paranaense}

\author{
Dimas Soares Júnior ${ }^{*}$; Philippe Pédelahore ${ }^{2}$; Ricardo Ralisch ${ }^{3}$; Nathalie Cialdella²
}

\begin{abstract}
During the period of 1950 through 2000, a green-revolution-based model mostly for commodities boosted global agricultural production. From the 70's, this design became consolidated in Brazil and other countries because of policies and strategies by states and private groups. However, some doubts has been raised on its environmental and socioeconomic issues, in special for family farming. This study aimed to contribute by identifying changes and resistance in agricultural structures, systems and demographic aspects of this model and its adoption by farmers. It was carried out in the state of Paraná - Brazil, within the microregion of Toledo and in the northern pioneer area, which represent the history and diversity of this state about socioeconomic and human aspects, as well as technical development. It was based on statistics of agricultural censuses (1970, 1975, 1980, 1985, 1996 and 2006), population censuses (1970, 1980, 1991, 2000 and 2010) and municipal agricultural production data (1980-2012). Data from both areas were compared to each other and analyzed in face of state changes. There has been a decrease in farming properties and rural population, with an outstanding decline in the number of young people and women. Moreover, results showed a large reduction of properties with 20 to 50 ha, and an increase in those of up to $2 \mathrm{ha}$. Such decline is due to technological standard changes throughout the period, as well as recent grants offered to rural areas, as housing and leisure spaces. Both regions showed expansion of soybean plantations, but integrating distinctively to agriculture and, finally, family farming continuity, despite the intense changes.
\end{abstract}

Key words: Family farming. Food crops. Rural demography. Agrarian structure. Soybeans.

\section{Resumo}

Durante o período de 1950 a 2000, o modelo de desenvolvimento agrícola pautado no conceito da revolução verde e voltado sobretudo para a produção de commodities permitiu um aumento significativo na produção agrícola global. A partir dos anos 70, este modelo foi consolidado no Brasil e em outros países como resultado da combinação de políticas e estratégias dos Estados e dos grandes grupos privados. A vigência desse modelo tem suscitado dúvidas sobre as suas consequências ambientais e socioeconômicas, particularmente quando adotado em sistemas de agricultura familiar. O trabalho tem por objetivo contribuir no debate desse tema identificando as mudanças e resistências nas estruturas agrárias, nos sistemas agrícolas e em aspectos demográficos relacionados com a difusão desse modelo e sua adoção pelos agricultores. O estudo foi realizado no estado do Paraná, na Microrregião de Toledo e no Território Norte Pioneiro, áreas que representam a história e a diversidade paranaense em seus aspectos de desenvolvimento socioeconômico, humano e técnico. Baseou-se na análise de dados estatísticos de

Pesquisador, Instituto Agronômico do Paraná, IAPAR, Londrina, PR, Brasil. E-mail: dimasjr@iapar.br

2 Pesquisadores, Centre de Coopération Internationale en Recherche Agronomique pour le Développement, CIRAD, Montpellier, França. E-mail: philippe.pedelahore@cirad.fr; nathalie.cialdella@cirad.fr

3 Prof., Universidade Estadual de Londrina, UEL, Londrina, PR, Brasil. E-mail: ralisch@uel.br

* Author for correspondence 
censos agropecuários (1970, 1975, 1980, 1985, 1996 e 2006), censos demográficos (1970, 1980, 1991, 2000 e 2010) e nos dados de produção agrícola municipal (1980-2012). Os dados foram comparados entre as duas áreas e analisados em alinhamento com as mudanças observadas no estado. Observa-se uma diminuição do número de estabelecimentos agropecuários e da população rural, com a redução, sobretudo, do número de jovens e de mulheres. Os resultados mostram ainda uma grande redução no número de estabelecimentos entre 20 a 50 ha e o crescimento do número de estabelecimentos de até 2 ha, consequências das mudanças no padrão tecnológico observadas no período e de atribuições oferecidas em período mais recente às zonas rurais, incorporadas como espaço de moradia e lazer. Observa-se ainda a expansão do cultivo de soja em ambas as regiões, porém com modalidades diferenciadas de inserção nos sistemas agrícolas e, finalmente, a permanência dos sistemas de agricultura familiar, apesar das intensas alterações observadas no período.

Palavras-chave: Agricultura familiar. Culturas alimentares. Demografia rural. Estrutura agrária. Soja.

\section{Introduction}

Brazilian agriculture has experienced intense transformation for the last 40 years, which brought results and effects now easily noticeable not only in rural areas, but also in our society as a whole. With increased production, the country avoided supply crises and prominently positioned in the international agribusiness, consolidating among the major world exporters of agricultural goods. Grain production, for example, increased from 23.3 to 194.7 million tons between 1970 and 2014 (CONAB, 2014). On the other hand, there was an intense rural exodus, with population decrease from 44 to $16 \%$, between 1970 and 2010 (IBGE, 2014a). It was mainly marked by the uncontrolled growth of poor outskirts in medium-sized cities and metropolitan areas. In parallel, questions about the impact of such changes from the social and environmental point of view have built up from the 1990s on.

These transformations, properly named as conservative modernization, kept the remarkable unequal agrarian structure in the country (GRAZIANO DA SILVA, 1982). Indeed, these are marks left by adopting an international farming model, the so-called green revolution based on mechanization, selection of plant varieties with better yield potential, and extensive use of inputs.

Even though Brazil is under fiscal crisis since the mid-1980s, with fewer rural credit policy of subsidies (RAMOS; MARTHA JUNIOR, 2010), technology remained, strengthening questions existing in other nations undergoing or have undergone through similar transformations (LERCHE, 2013; ZHANG; DONALDSON, 2010). What is the future of family farming since agricultural production dispenses with more and more human work, intensifying technology and capital?

Such issues are still constant in Brazil. Despite the orthodox thinking of liberal or Marxist inspiration predicting the disappearance of family farming , this model has not only pulled through within the interstices of the country's landholding concentration, but also consolidated itself. In 2005 , it accounted for $32 \%$ of the agribusiness gross national product (GNP) and $9 \%$ of the total Brazilian GNP (GUILHOTO et al., 2007).

According to the agricultural census, it increased to $38 \%$ GP and $74 \%$ farming workers in 2006 . These are data from over 4 million production units, which cover $84 \%$ of the total, but only $24 \%$ of the occupied area (IBGE, 2006).

The national scene is particularly evidenced in Paraná state, wherein, in addition to traditional economic challenges for the future of family farming, such as production scale, access to technology and capital goods, issues such as masculinization and aging of the rural population are evident (SACCO DOS ANJOS et al., 2014). Besides of that, other factors has outstood as uncertainty of family succession in production units (BAZOTTI et al., 2009) and conflicts between farm production and 
environment protection legislation (KLEIN et al., 2015).

Thus, although the changes observed have common features, it is suggested that they resulted in different impacts and evolution patterns when considering the different state regions. Therefore, regional wise analyses are relevant to identify farming changes, as well as knowing their current activities and provide answers to the questions above.
Therefore, this paper aimed to present the changes in farming systems in two regions of Paraná state. These areas were marked by different characteristics on historical occupation in the past and different degrees of rural development in the present. These areas cover the microregion of Toledo and the northern pioneer territory (Figure 1), taking as a limit the condition observed at state level.

Figure 1. Location of the study regions.

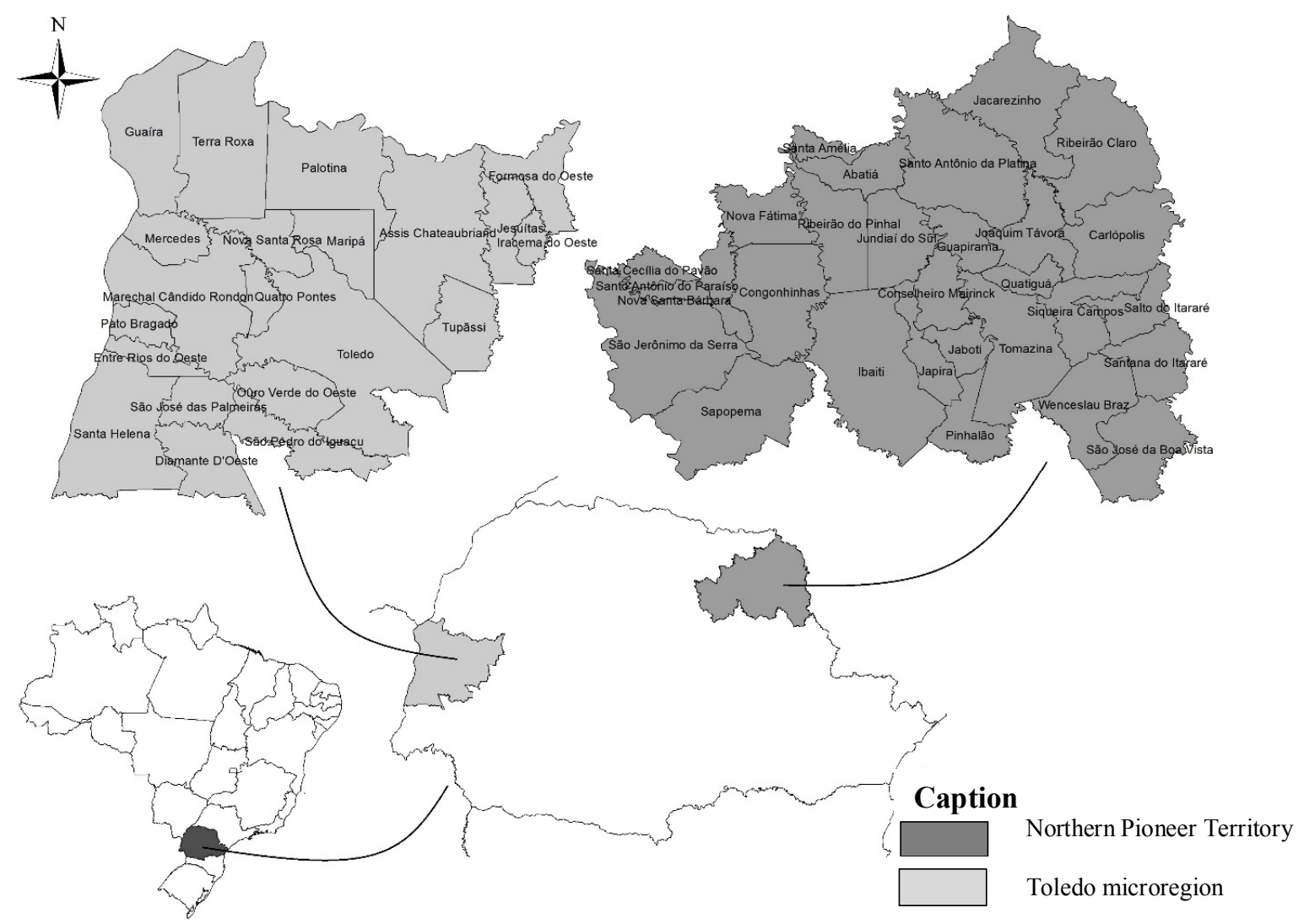

Sources: IBGE (2014b) and IPARDES (2007).

Variables such as number and size of rural properties, population, rural and urban households, land use and agricultural production were selected for this evaluation. The results are displayed in three topics; the first one outlines the agrarian structure and households, the second covers crop production, and the third discusses demographic aspects.

\section{Material and Methods}

The study is based on diachronic analysis with regional sections, based on the comparative agriculture approach (COCHET et al., 2007; COCHET, 2012), used in Pedelahore (2014), among others. Data on rural properties and land use were 
collected in the agricultural census (1970, 1975, 1980, 1985, 1996 and 2006), using the demographic censuses (1970, 1980, 1991, 2000 and 2010) for collecting the data on population and households. Figures related to the cultivated area (1980 to 2011) are from the "Municipal Agricultural Production" (MAP). These three different sources are under the Brazilian Institute of Geography and Statistics (IBGE); its System of Automatic Recovery - SIDRA (IBGE, 2014a) was used for data collection and, if necessary, the census printed versions. Production gross values were taken from state database of the Paraná State Department of Agriculture and Supply (DERAL/SEAB) accessed in the state database (IPARDES, 2014).

Data collection was performed at the municipal level, and the installation dates of the new municipalities founded from the year of initial analysis on (1970) were observed for the composition of the two study areas, as well as their territory dismemberment processes. Then, information was gathered in spreadsheets according to the regions defined. When necessary, concepts of the collected variables are presented their discussion. The procedures used in the calculation of derived variables are also presented along the text.

\section{Results and Discussion}

Agrarian Structure and Households: Small farm emergence and decline of estates

Looking at the most recent change period, the total number of rural properties between 1996 and
2006 remained stable in Paraná and in the northern pioneer territory, having been reduced by $13 \%$ in the microregion of Toledo. There have been major changes, however, when the figures for total area groups observed in the last two census periods are taken into account (Figure 2).

Indeed, farms smaller than 2 ha uniquely increased share in the state and in the studied regions, more than doubling its relative presence in Paraná properties and in the microregion of Toledo. At state level, the number of properties was reduced in all other area strata, especially in the strata between 20 to 50 and 5 to 10 ha.

In the northern pioneer territory, there was an increase in the number of properties, also in the two other strata of smaller areas - from 2 to 5 and 5 to 10 ha, with reductions focusing on properties between 50 to 100 and 20 to 50 ha. On the other hand, in Toledo, the other strata with increasing number of properties were those with areas above 100 ha; thus, concentrating the decrease in total properties in the strata of 10 to $20 \mathrm{~h}$ and 20 to $50 \mathrm{~h}$.

In general, it appears that properties between 20 and 50 ha, within the most important stratum for family farming, reduced its share. On the other hand, there is an increase in number of properties within the smaller area strata. Most of them are potentially in a new rurality context, comprising it not only as agricultural production area, but also as living and recreation spaces. These data corroborate those noted by Hoffmann and Ney (2010) when analyzing an agricultural census from 2006, for large regions and states. 
Figure 2. Number of properties per total area groups. Paraná State, Northern Pioneer territory and the Toledo microregion. 1995 and 2006.
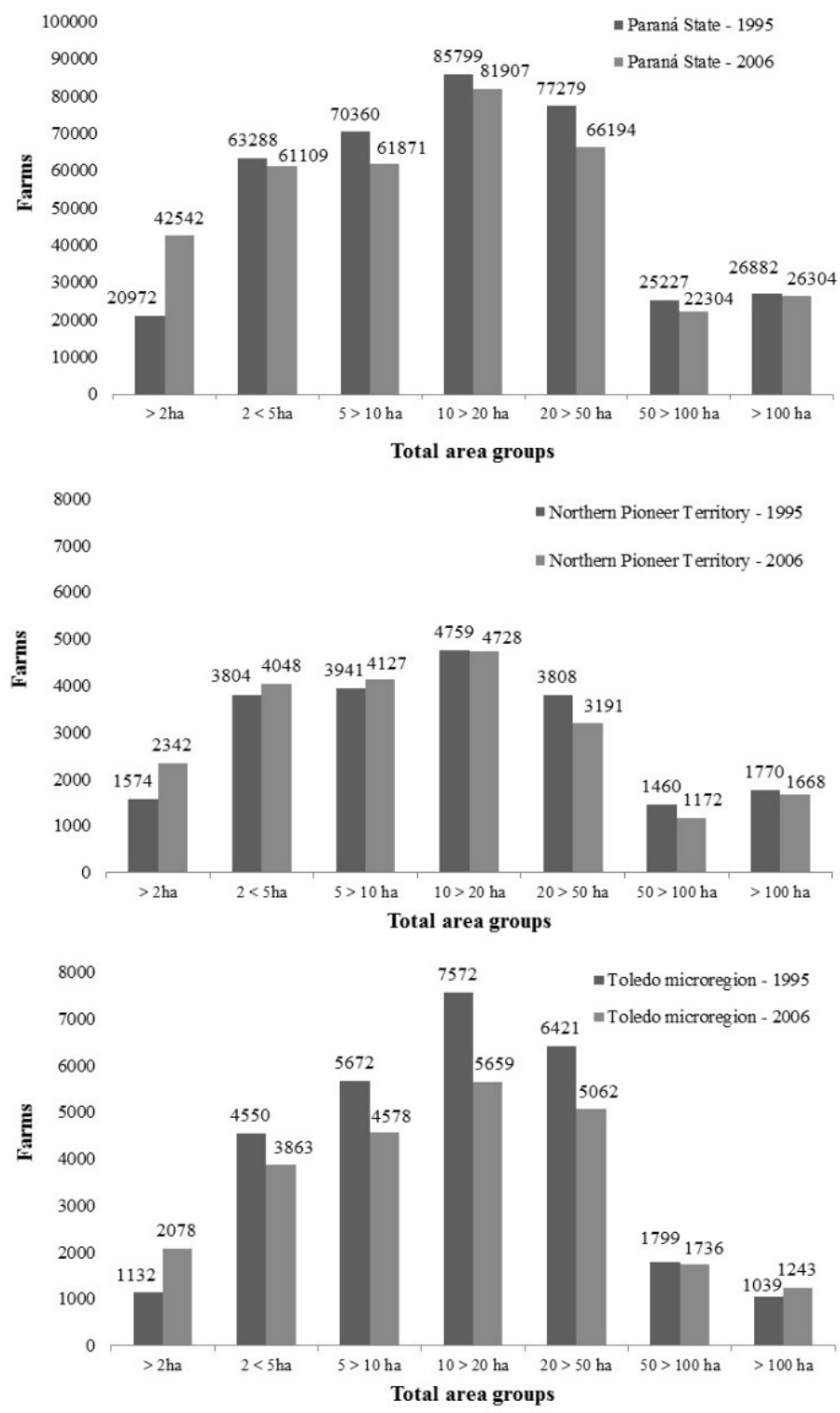

Source: IBGE (2014a).

About housing, smaller-area strata growth was sped up by building 21 "Rural Villages"4 within

4 With the general objective of improving the living conditions of migratory rural workers, keeping them in rural areas (SOUZA; DEL GROSSI, 2000), the Rural Villages were settled in sites close to urban centers of the state, including districts and villages. With lots of $5,000 \mathrm{~m}^{2}$ and houses of $44 \mathrm{~m}^{2}$ they had, in addition to the basic feeding function, the prospect of receiving other activities, however the land wasn't the only family income source. The underlying basic idea was that residents could work in neighboring farms, but would develop subsistence crops on their lands, selling the surplus.
Toledo microregion, between 1995 and 2003; such building venture totaled 615 eligible families, In the northern pioneer territory, 32 rural villages were built, benefiting 1,250 families (verbal statement) 5 . As for leisure, this observation is reinforced when the evolution of unoccupied households of occasional

\footnotetext{
${ }^{5}$ Information provided upon request by the Paraná Real Estate Department of Housing (COHAPAR), the program's management agency.
} 
use $^{6}$ in recent times is considered, whose number increases in rural areas in compatible proportions, or even higher, as observed at the state level, to those observed in urban areas (Figure 3).

Otherwise, the analysis of changes in permanent households ${ }^{6}$ (Figure 4) shows that those found in rural areas had their numbers lessened to more than half, from 1970 to 2010, in the microregion of Toledo and in the northern pioneer territory. It was opposed to their rapid growth in urban areas, where they were multiplied about nine times in Toledo, five times in the state and three times in the northern pioneer territory, region where urban economic activities have a lower ability of attraction (TURRA; MELO, 2014).

Figure 3. Total non-occupied private households, of occasional housing use. Paraná State, Northern Pioneer territory and the Toledo microregion. $1991-2010$.
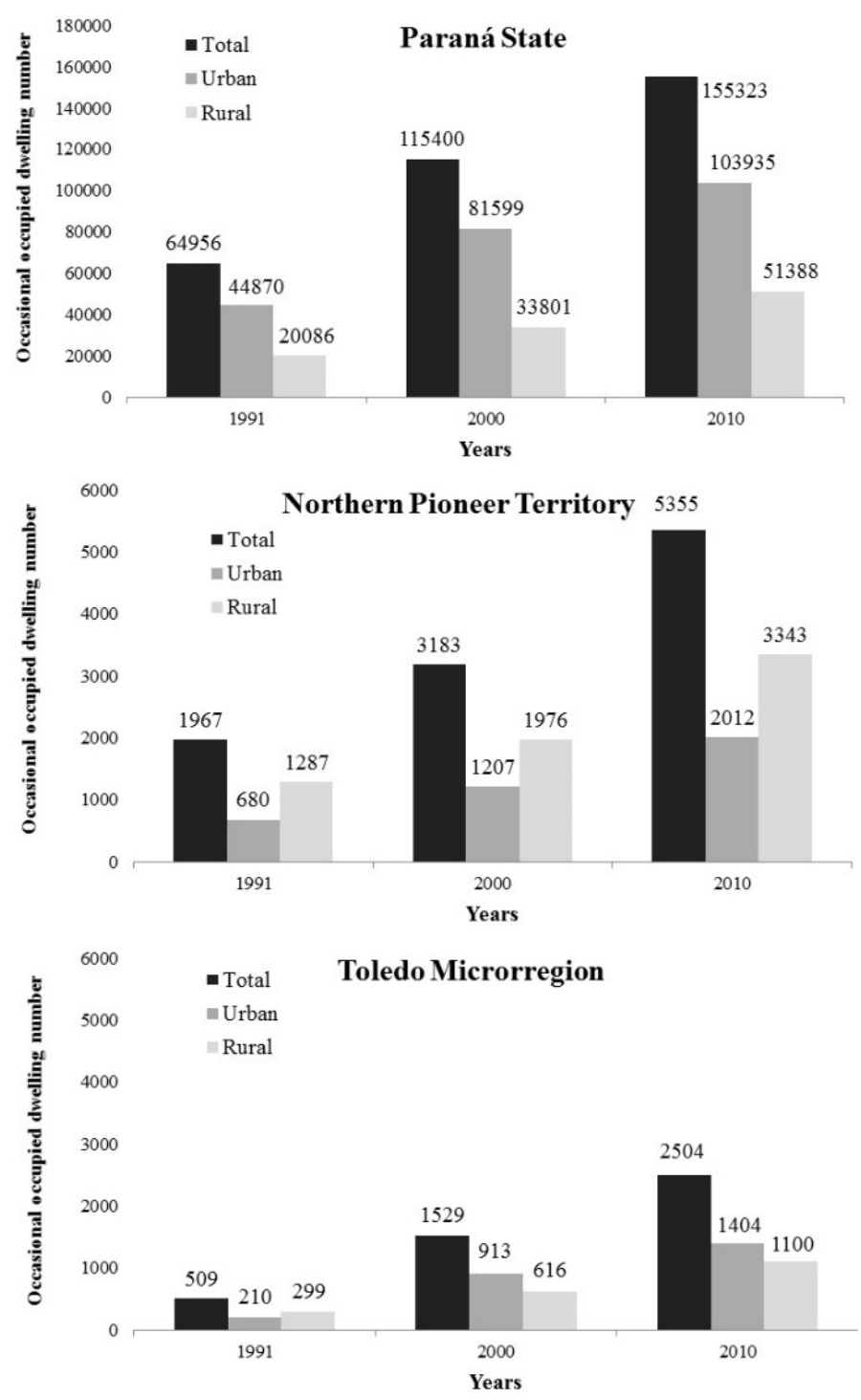

Source: IBGE (2014a).

${ }_{6}$ They are characterized as being the permanent private households which at the reference date served occasionally as housing. That is, those used for weekends of rest, vacation or other purpose, even if on the date of reference their occasional occupants were present (IBGE, 2010). 
Figure 4. Total of permanent private households, by housing situation. Paraná State, Northern Pioneer territory and the Toledo microregion. $1970-2010$.
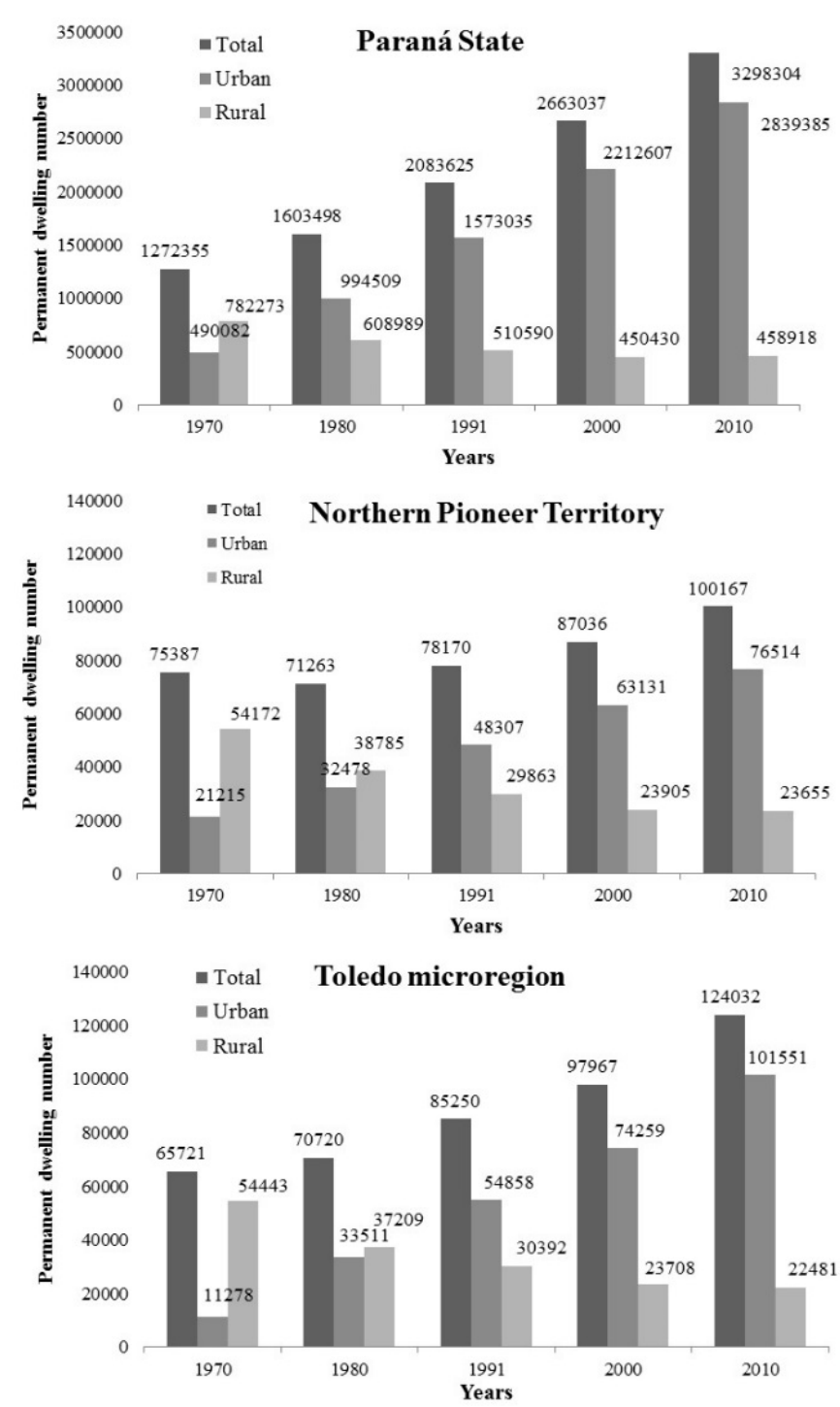

Source: IBGE (2014a).

Changes in share in the number of properties by total area groups did not significantly change the concentration of land in the upper area strata. The most important is to stress that in the state and regions studied the rule of the group with areas larger than 100 ha was evident, which reinforced its majority stratum condition, having advanced especially in the microregion of Toledo. In Parana, the strata from 20 to 50 and 5 to 10 ha showed losses of 15 and $12 \%$ in the area they occupy, whereas in the northern pioneer territory losses concentrated in the strata from 50 to 100 and 20 to 50 ha, which lost 19 and $17 \%$ of area, respectively. In the microregion of Toledo, the greatest losses were for 10 to 20 -ha strata, being reduced by $25 \%$. In the strata from 20 to 50 and 5 to 10 ha, the drop was $20 \%$ of losses in total occupied area (Figure 5). ${ }^{7}$

\footnotetext{
7 It is a construction built to serve exclusively for housing purposes, which served as house for one or more people, on the reference date (IBGE, 2010).
} 
Figure 5. Total area relative share of properties, considering different size groups. Paraná State, Northern Pioneer territory and the Toledo microregion. 1995 and 2006.
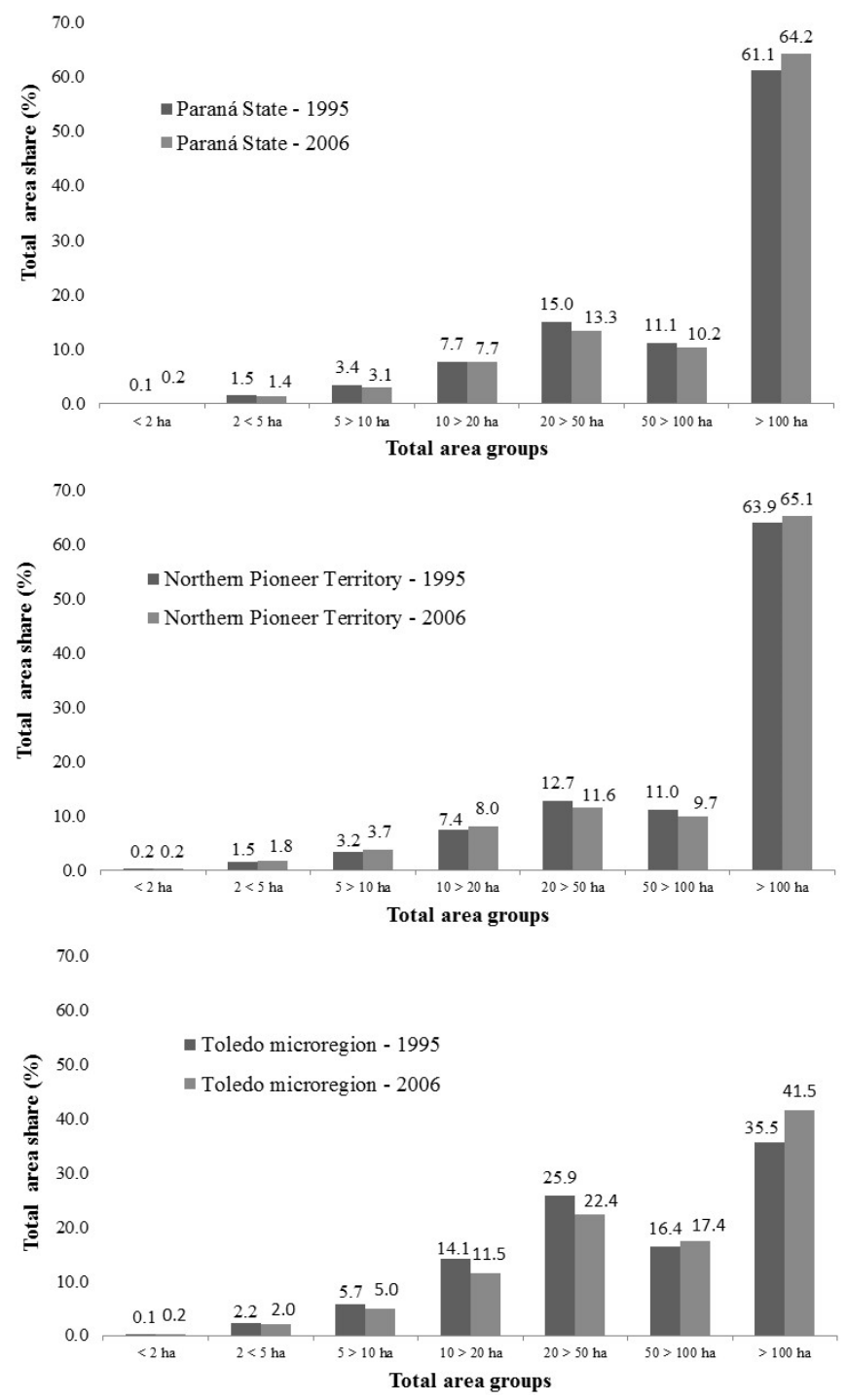

Source: IBGE (2014a).

Production: "Soyfication in the Paraná fashion"

Land use also changed in the period, remarking a growth of $62 \%$ in seasonal crop areas in Paraná, which increased especially between 1970 and 1975 . Between 1970 and 2006 there was a decrease in the areas of permanent crops and natural pasture,

8 Soyfication is the term coined to describe the significant growth of the soybean crop phenomenon in Argentina due to the large protein demand at the global level, which was marked by expansion in cultivated area and technological gains (CAFIERO, 2004 apud BARBOSA; NOGUEIRA JÚNIOR, 2007). an increase in planted pastures showing an intensification in the cattle industry, and expansion in natural forests and, above all, planted forests (Figure 6). Such movements are associated with the number of properties and their total exploited area, and result in increased estimated mean for agricultural area in use (AA) ${ }^{9}$, which between 1970 and 2006 went from 16.6 ha to 30.3 ha.

\footnotetext{
${ }_{9}$ Corresponds to the sum of the permanent crop area + temporary crop area + natural pasture area + planted pasture area, divided by the total number of properties.
} 
Figure 6. Changes in land use of agricultural properties. Paraná State. 1970 - 2006.

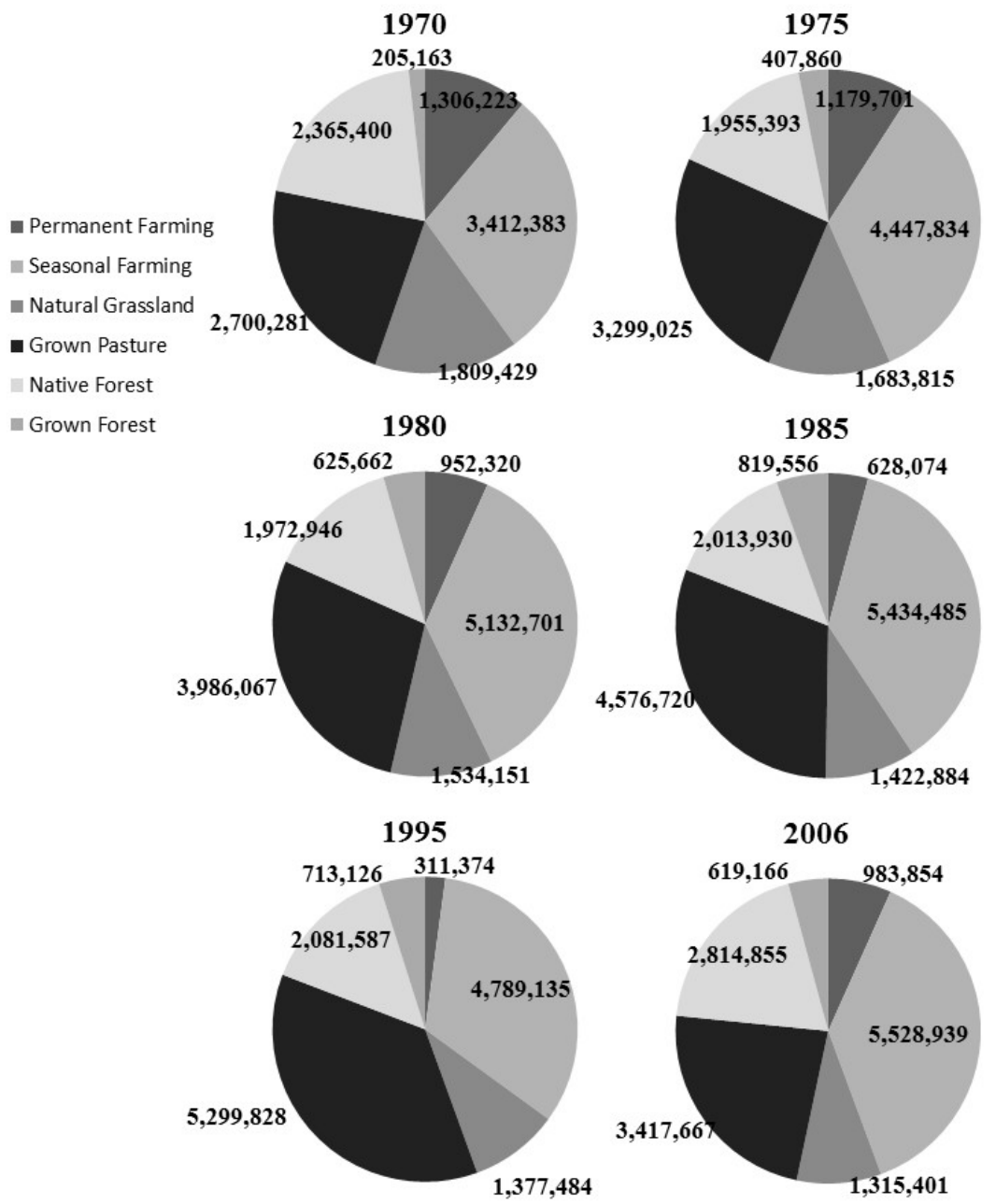

Source: IBGE (2014a).

The agenda of the major state agricultural producers towards the cultivated area (IBGE, 2014a) explains such changes, which arise in particular from the growth of the areas dedicated to soy cultivation since 1980, heavily accented between 1995 and 2005. The maize crop, which apart from oscillations keeps the second place, wheat, albeit declining, and beans complete the main group of seasonal crops over the period. The growth in areas dedicated to sugarcane and the decline of coffee, cotton and rice crops stand out, with the latter traditionally devoted to consumption.
Regarding the common hegemony point of areas dedicated to soy cultivation, the two study regions hold different characteristics about the use of their crop areas. In the northern pioneer territory this oleaginous gains importance from the 2000s on, having rivaled with crop fields of corn and wheat up to the middle of that decade. In this region, production variations can be evidenced also by the decline in bean and coffee crops, which were outstanding activities in the $80 \mathrm{~s}$, and the growth of sugarcane fields, also viewed in the last decade (Figure 7). 
Figure 7. Ongoing evolution of seasonal cropping areas. Northern Pioneer territory. 1980 - 2011.

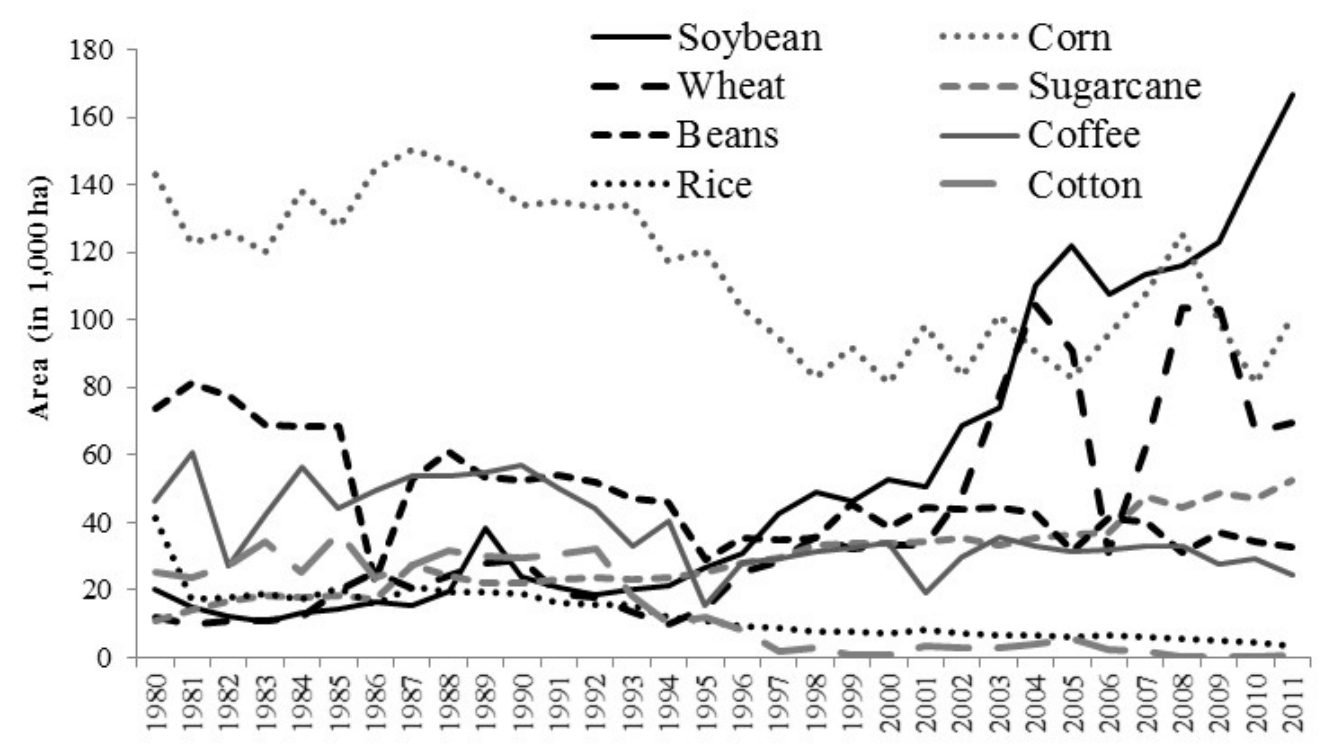

Source: IBGE (2014a).

Recent analyses on agricultural gross production (GP) shows that the sector is predominant in the northern pioneer territory. Also considering the GP of agricultural products, plus milk, the importance and cyclical changes of coffee crop can be observed, as well as the recent lead taken by soybeans, whose contribution went from $4.7 \%$ to $23.6 \%$, between 1980 and 2011. Apart from that, it may be cited the decline in relative importance of beans, whose share was reduced from $17.1 \%$ to $2.9 \%$ in the same period (IPARDES, 2014).

In Toledo, areas grown with seasonal crops concentrated on the three key crops of the grain production: soybean, corn and wheat (Figure 8). Soybean and corn are part of the powerful complex of animal protein found in the region, which advanced in the West region (comprising the microregions of Toledo and Cascavel) based on

"[...] poultry and swine farming expansion mainly connected to the cooperative sector. Poultry production started with contracts of integration between agribusiness and producers in the 1960s, [...] at the time, agribusinesses favored small producers with diversified production and self-employed family labor. Among other things, this strategy was intended so the producers themselves would provide inputs for animal feed, soybean and corn mainly, not only lowering production costs, but also the family maintenance costs. Today, technological increments as animal feeding mechanization and aviary temperature control [...] a business relationship is set in management and employment fields, as well as dependence of supply chain in the activity. “(IPARDES, 2008 apud SILVA, 2011, p.11). 
Figure 8. Ongoing evolution of seasonal cropping areas. Toledo microregion of. $1980-2011$.

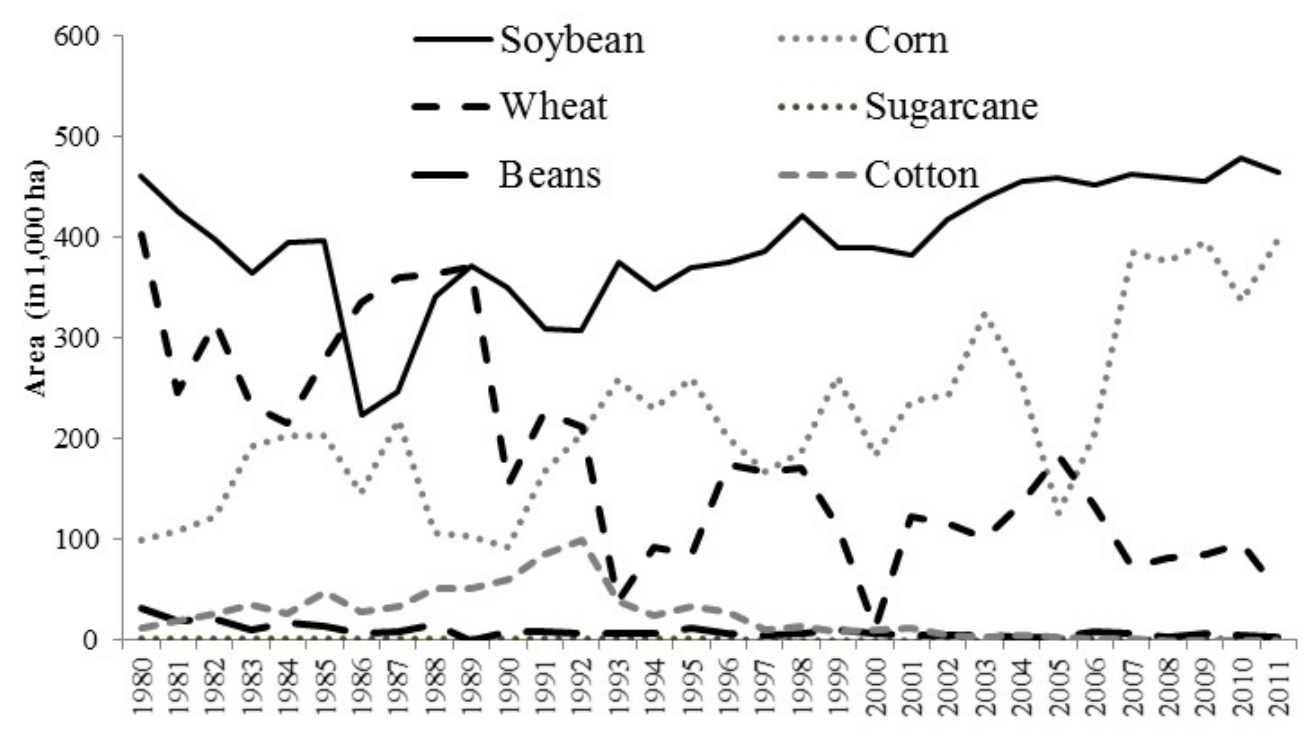

Source: IBGE (2014a).

Thus, only poultry and swine farming alone guarantee the supremacy in the composition of total GP, having contributed an average share of $35 \%$ from 2007 to 2011. When considering the GVP evolution of agricultural products plus milk, the leadership of soybean is noted, with $62.9 \%$ share in 2011 (IPARDES, 2014), as well as the decline of corn, which gives milk production the second place. Considering corn increasing importance in cropping areas, grain production and dairy became consolidated, especially in family units (LANGE et al., 2016), making corn as livestock feeding with certainty of added value.

The approach adopted in Toledo microregion consisted of technical progress with increase in labor, crop and activity yields, as well as a vertical integration to exporter agribusiness, (MADUREIRA, 2012). In addition, labor in nonagricultural rural occupations and outsourcing of operations were also observed (LAURENTI et al., 2003).
Population: masculinization and aging in the field

Changes in the agrarian structure and production systems naturally condition and are conditioned by changes in demographics, which are clearly seen in the state and in the study regions within the period discussed. It is observed that in 1980 the Paraná population was predominantly urban $(58.6 \%)$, a condition achieved in the regions studied only years later, with an urbanization rate of $85.3 \%$ in 2010 in Paraná, which is higher than what was observed in the microregion of Toledo (70.3\%) and the northern pioneer territory $(70.8 \%)$.

The change analysis indicates that at state level, while urban population nearly doubled in number, rural population decreased by half. The strong migration in the period together with changes in birth rates and life expectancy altered population composition regarding gender and dwelling place. Between 1980 and 2010, male urban population grew $96.5 \%$ while female one $102.0 \%$. However, the number of women in farming areas reduced more than that of men $(-51.8 \%$ and $-51.2 \%)$. Additionally, while in the cities general population growth widens as age increases, the reduction in 
rural area is continuing to the range of 55 years old for men and 50 for women, from when population starts to be ascending from these ages on.

In the northern pioneer territory, total population decreased by $6.5 \%$ in the period from 1980 to 2010 , with urban population growth at $67.6 \%$, and rural population reduction at $60.2 \%$ in the same period. The number of men in cities also grew less than the number of women $(+66.5 \%$ vs. $+68.7 \%)$, and in rural areas it was reduced to a lesser extent $(-59.6 \%$ men, $-60.9 \%$ women). Rural population decreased almost continuously until the age of 70 for men and women, and slight increases were observed from that age on.

In the microregion of Toledo, between 1980 and 2010 , the total population increased by $7.2 \%$, having grown $93.0 \%$ in cities and reduced by $63.1 \%$ in rural areas. In this region, the phenomenon of increased growth of the female urban population was also observed $(+97.0 \%$ women and $+89.1 \%$ men). Different from that observed in the state and north pioneer, however, the reduction in the number of women in the field was smaller than that of men (-62.9\% compared to $-63.2 \%$ ), from 55 to 60 years old among women and men respectively, age after which the rural population increased.
Regarding changes in age composition, the conditions reported are best observed when dependency ratios are analyzed, defined (IBGE, 2012) as the existing number of non-active individuals (children $\leq 15$ years old, and the elderly, $>65$ years old) for every 100 economically active inhabitants (between 15 and 65 years old). It is observed that the number of non-active individuals in rural populations, which was notably higher than that of urban populations in the state and regions studied in 1980, decreased more intensely in the following years, reaching compatible values between rural and urban areas in 2006 (Figure 9).

As for gender ratio, the number of men for every 100 women in the population (IBGE, 2012) indicates a change in the population profile when calculated for young people between 15 and 24 years old. The predominance of men in rural areas is noted in this stratum in particular, but there are ratios which grow and approximate parity in urban areas, pointing out that migration rural - city in this age group was more intense among young women (Figure 10). These results corroborate those observed by Sacco dos Anjos et al. (2014) in the analysis for the southern region of Brazil, and may culminate in the phenomenon of "rural celibacy", as discussed by Costa (2013), resulting in negative consequences to the already complex succession condition in family production units. 
Figure 9. Dependency ratio in urban and rural populations. Paraná State, Northern Pioneer territory and the Toledo microregion. $1980-2010$.
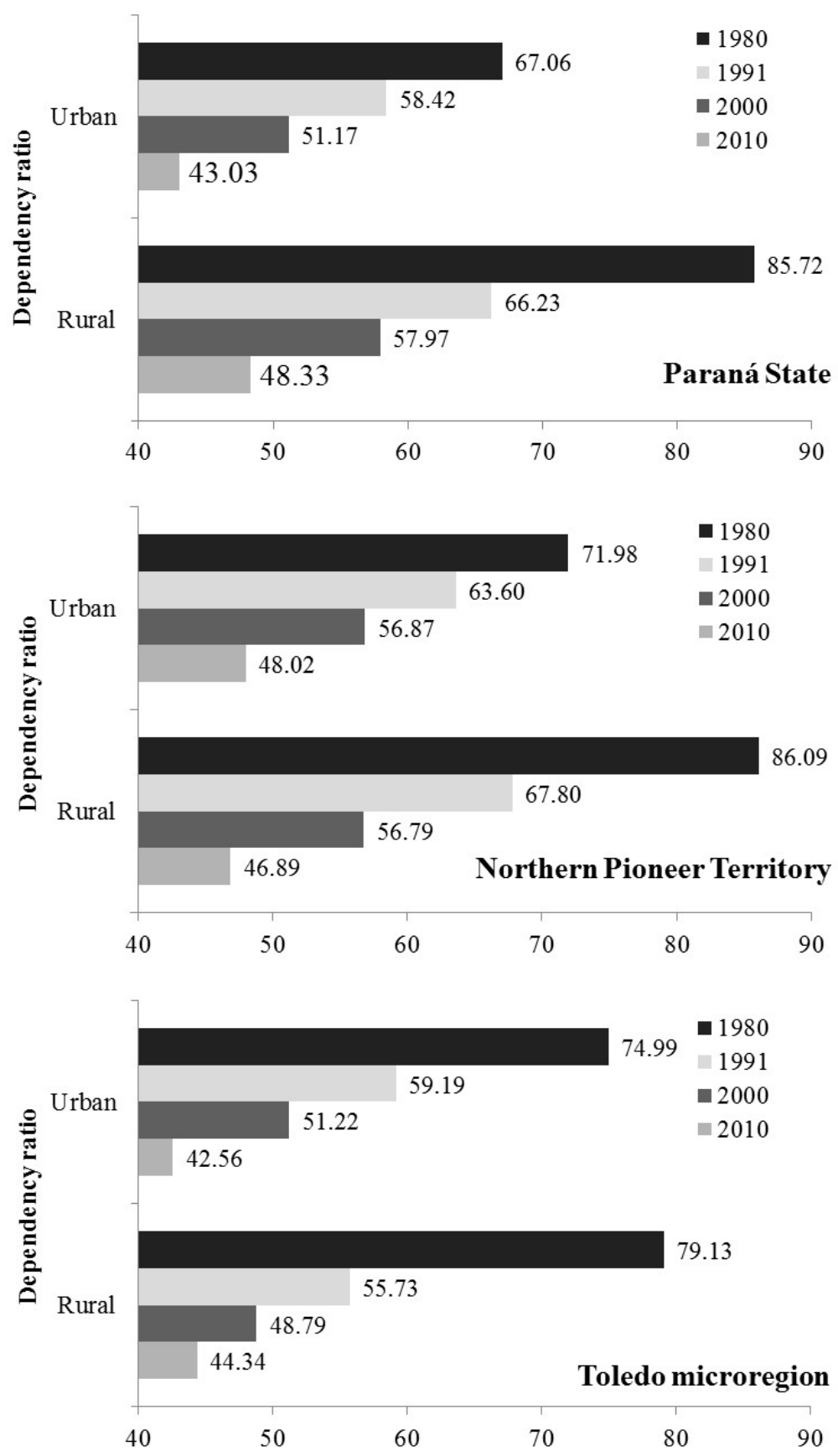

Source: IBGE (2014a). 
Figure 10. Gender ratio within population between 15 and 24 years old, according to housing location. Paraná State, Northern Pioneer territory and the Toledo microregion. 1980 - 2010.

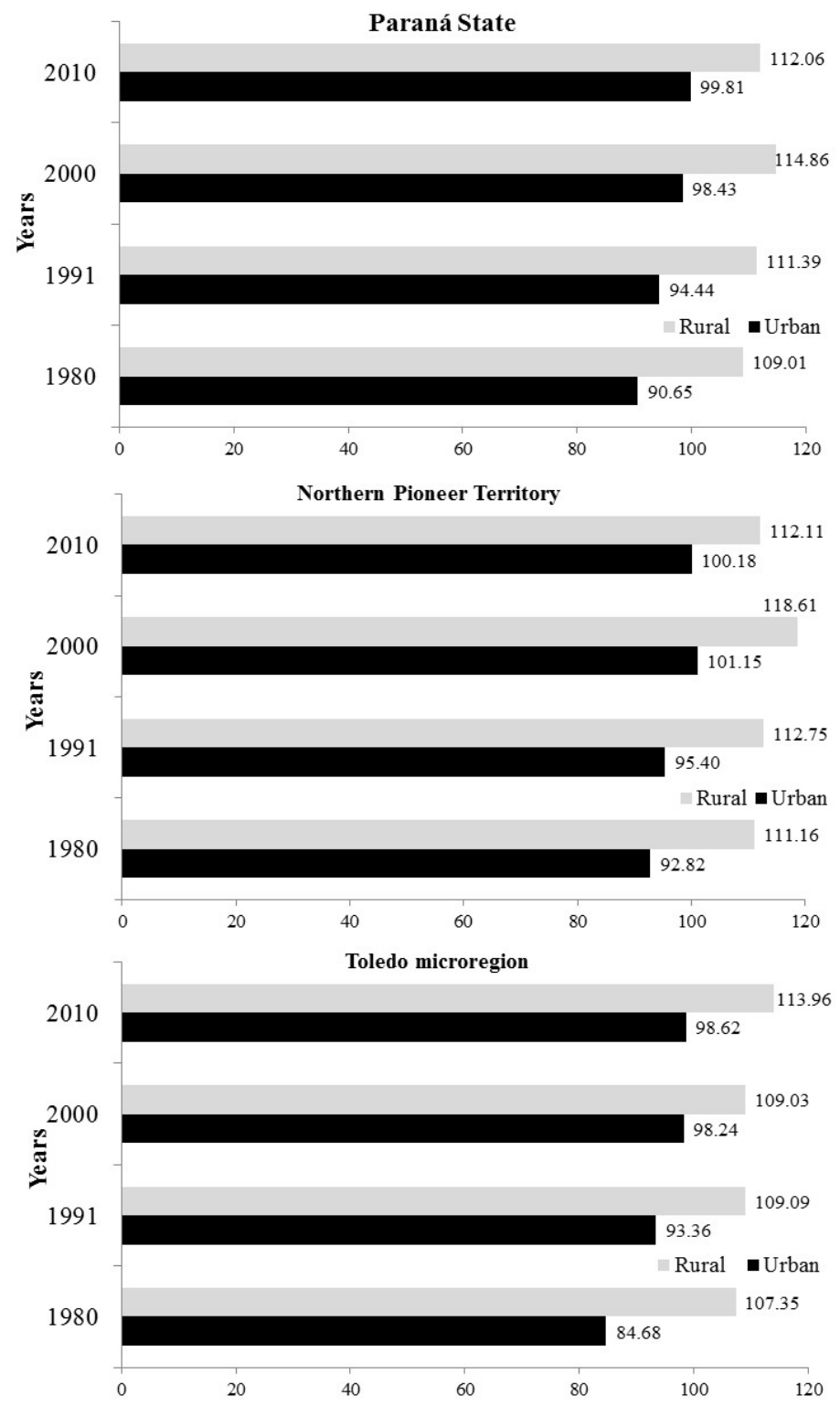

Source: IBGE (2014a).

\section{Conclusions}

The rural scenario in Paraná has faced a process of intense transformations over the last decades. About $30 \%$ of rural properties have disappeared, population has decreased, aged and become more masculine. In the study areas, the number of properties with small areas apparently intended for leisure increased, growing crops changed and complex agro-industrial systems as soybeans and animal protein, has consolidated.

Family farming was the one that has mostly changed. The number of large-sized properties decreased, however, mechanization, average area of exploitation and labor productivity increased, expanding the need for changes arising from integration to markets through the agro-industrial 
complexes under consolidation, a particularly intense process in the microregion of Toledo. This resulted in the observation of the largest rural development rate in the state (TURRA; MELO, 2014).

On the other hand, this model faces sustainability challenges as more strict environmental laws (TOMAZELLA, 2010) and economic and social issues. For instance, urban and non-agricultural activities growing faster in number and yield (LAURENTI, 2013) and daily decreasing number of further family successors (BAZOTTI et al., 2009) are factors that justify the considerations highlighted in this study should be considered in discussion and for formulation of new development policies and actions to be taken.

Finally, it appears that even in face of the changes described here in the context of regional agricultural systems, in both areas about $80 \%$ are still family properties (IBGE, 2006), indicating adaptations by this category of growers, allowing them to cope with such changes.

\section{Acknowledgements}

The authors would like to acknowledge the Coordination for the Improvement of Higher Education Personnel (Coordenação de Aperfeiçoamento de Pessoal de Nível Superior CAPES) for offer the doctoral sandwich scholarship grants for the first author.

\section{References}

BARBOSA, M. Z.; NOGUEIRA JÚNIOR, S. Simetrias entre as agroindústrias da soja no Brasil e na Argentina. Revista de Economia Agrícola, São Paulo, v. 54, n. 1, p. 87-107, jan./jun. 2007.

BAZOTTI, A.; NAZARENO, L. R. D.; CINTRA, A. P. D. U. Um ensaio sobre as famílias agrícolas paranaenses a partir das PNADs 1992, 1998, 2005 e 2007. Revista Paranaense de Desenvolvimento, Curitiba, v. 30, n. 117, p. 123-145, jul./dez. 2009.
BRASIL. Lei $n^{\circ} .11 .326$, de 24 de julho de 2006. Dispõe sobre as diretrizes para a formulação da Política Nacional da Agricultura Familiar e Empreendimentos Familiares Rurais. Brasília, Poder Executivo, 2006. Disponível em: <http://www.planalto.gov.br/ccivil_03/_ato20042006/2006/lei/111326.htm>. Acesso em: $1 \overline{7}$ out. 2013.

COCHET, H. The systeme agraire concept in francophone peasant studies. Geoforum, Dublin, v. 43, n. 1, p. 128136, jan. 2012.

COCHET, H.; DEVIENNE, S.; DUFUMIER, M. L'agriculture comparée, une discipline de synthese? Economie Rurale, Paris, v. 59, n. 297-298, p. 99-112, jan./mar. 2007.

COMPANHIA NACIONAL DE ABASTECIMENTO CONAB. Indicadores da agropecuária. Brasília: Conab, 2014. Disponível em: <http://www.conab.gov.br/conab/ Main.php?MagID=3\&MagNo=256>. Acesso em: 25 nov. 2014

COSTA, C. da. Contornos do celibato no espaço rural: solteirões do sul do Brasil. Extensão Rural, Santa Maria, v. 21, n. 3, p. 22-51, set./dez. 2013.

GRAZIANO DA SILVA, J. A modernização dolorosa: estrutura agrária, fronteira agrícola e trabalhadores rurais no Brasil. Rio de Janeiro: J. Zahar, 1982. 192 p.

GUILHOTO, J. J. M.; AZZONI, C. R.; SILVEIRA, F. G.; ICHIHARA, S. M.; DINIZ, B. P. C.; MOREIRA, G. R. C. PIB da agricultura familiar: Brasil - Estados. Brasília: Ministério do Desenvolvimento Agrário, 2007. 172 p. (NEAD Estudos; 19).

HOFFMANN, R.; NEY, M. G. Estrutura fundiária e propriedade agrícola no Brasil, grandes regiões $e$ unidades da federação. Brasília: Ministério do Desenvolvimento Agrário, 2010. 108 p.

INSTITUTO BRASILEIRO DE GEOGRAFIA E ESTATÍSTICA - IBGE. Censo Agropecuário 2006 Agricultura Familiar - MDA/PRONAF - Lei no 11.326 de 24/07/2006. Rio de Janeiro: IBGE, 2006. Disponível em: $\quad<$ http://www.sidra.ibge.gov.br/bda/pesquisas/ca/ defaultMDA.asp? $\mathrm{z}=\mathrm{p} \& \mathrm{o}=2 \& \mathrm{i}=\mathrm{P}>$. Acesso em: 21 nov. 2014.

Censo demográfico 2010 - glossário. Rio de Janeiro: IBGE, 2010. Disponível em: <http://censo2010. ibge.gov.br/materiais/guia-do-censo/glossario>. Acesso em: 8 set. 2014.

Indicadores sociais mínimos - conceitos. Rio de Janeiro: IBGE, 2012. Disponível em: <http://www. ibge.gov.br/home/estatistica/populacao/condicaodevida/ indicadoresminimos/conceitos.shtm>. Acesso em: 8 set. 2014. 
Sistema IBGE de Recuperação Automática - SIDRA. Rio de Janeiro: IBGE, 2014a. Disponível em: $<$ http://www.sidra.ibge.gov.br/bda/agric/default. asp? $\mathrm{z}=\mathrm{t} \& \mathrm{o}=11 \& \mathrm{i}=\mathrm{P}>$. Acesso em: 3 set. 2014.

Divisão territorial brasileira. Rio de Janeiro: IBGE, 2014b. Disponível em: <http://www.ibge.gov. br/home/geociencias/cartografia/default_dtb_int.shtm>. Acesso em: 1 ago. 2014.

INSTITUTO

DE DESENVOLVIMENTO ECONÔMICO E SOCIAL IPARDES. Diagnóstico socioeconômico do Território Norte Pioneiro: $1^{\text {a }}$ fase: caracterização global. Curitiba: IPARDES, 2007.

Base de Dados do Estado - BDEweb. Curitiba: IPARDES, 2014. Disponível em: <http://www.ipardes. pr.gov.br/imp/index.php>. Acesso em: 12 set. 2014.

KLEIN, L.; FRAGALLI, A. C.; PANHOCA, L.; GARCIAS, P. M. Mudanças do código florestal: uma análise institucional da percepção de produtores agrícolas de um Município do Paraná. Revista de Gestão Ambiental e Sustentabilidade-GeAS, São Paulo, v. 4, n. 1, p. 124-138, jan./abr. 2015.

LANGE, M. J.; ZAMBOM, M. A.; RAMOS, C. D. O.; CASTAGNARA, D. D.; BÁNKUTI, F. I.; NEUMANN, M. E.; BRITO, M.M; TININI, R. C. R. Typology of dairy production systems based on the characteristics of management in the Region of West Paraná. Semina: Ciências Agrárias, Londrina, v. 37, n. 1, p. 473-481, jan./ fev. 2016.

LAURENTI, A. C. Evolução da ocupação e rendimento das pessoas no meio rural do Paraná no período 20012009. Revista Paranaense de Desenvolvimento, Curitiba, v. 34, n. 124, p. 175-199, jan./jun. 2013.

LAURENTI, A. C.; DORETTO, M.; DEL GROSSI, M. E. Ocupação e renda nas famílias das áreas rurais na região lindeira do lago de Itaipu. In: CONGRESSO BRASILEIRO DE ECONOMIA E SOCIOLOGIA RURAL, 41., 2003, Juiz de Fora. Anais... Juiz de Fora: Sociedade Brasileira de Economia e Sociologia Rural, 2003. p. 252-270.

LERCHE, J. The agrarian question in neoliberal India: Agrarian transition bypassed? Journal of Agrarian Change, Oxford, v. 13, n. 3, p. 382-404, 2013.
MADUREIRA, E, M. P. Análise das principais cadeias de produção agropecuárias no processo de crescimento econômico do Oeste do Paraná: 1985 - 2010. 2012. Dissertação (Mestrado em Desenvolvimento Regional e Agronegócios) - Universidade Estadual do Oeste do Paraná, Toledo.

PEDELAHORE, P. Systèmes agroforestiers à cacaoyers et transition capitaliste: l'exemple du Centre-Cameroun. Bois et Forêts des Tropiques, Montpellier, v. 321, n. 3, p. 55-66, 2014.

RAMOS, S. Y.; MARTHA JÚNIOR, G. B. Evolução da política de crédito rural brasileira. Planaltina: Embrapa Cerrados, 2010. 65 p. (Documentos, 292).

RIPPEL, R. Migração e desenvolvimento econômico no Oeste do Estado do Paraná: uma análise de 1950 a 2000. 2005. Tese (Doutorado em Demografia) - Instituto de Filosofia e Ciências Humanas, Universidade Estadual de Campinas, Campinas.

SACCO DOS ANJOS, F.; CALDAS, N. V.; POLLNOW, G. E. Menos mulheres, menos jovens, mais incertezas. A transição demográfica no Brasil Rural Meridional. Extensão Rural, Santa Maria, v. 21, n. 2, p. 94-116, abr./ jun. 2014.

SILVA, G. R. D. A pobreza e a dinâmica espacial do trabalho nos frigorificos de aves no oeste paranaense. 2011. Dissertação (Mestrado em Geografia) Universidade Estadual do Oeste do Paraná, Toledo.

SOUZA, M.; DEL GROSSI, M. E. As vilas rurais no Estado do Paraná: uma política não-agrícola com viés agrícola. Reforma Agrária, Campinas, v. 30, n. 3, p. 61 84, 2000.

TOMAZELLA, P. D. Agricultura e meio ambiente: agricultura familiar e reserva florestal legal em Palotina, Paraná.2010. Dissertação(MestradoemDesenvolvimento Regional e Agronegócio) - Universidade Estadual do Oeste do Paraná, Toledo.

TURRA, S.; MELO, C. O. de. Subsídios para análise do desenvolvimento rural das microrregiões do Estado do Paraná. Extensão Rural, Santa Maria, v. 21, n. 2, p. 6174, abr./jun. 2014.

ZHANG, Q. F.; DONALDSON, J. A. From peasants to farmers: Peasant differentiation, labor regimes, and landrights institutions in China's agrarian transition. Politics \& Society, New York, v. 38, n. 4, p. 458-489, 2010. 